The Spatial Frame of Lifelong Learning: Learning Regions, Learning Cities, Learning Communities

\section{Magdolna Benke}

Hungarian Educational Research Journal 2015, Vol. 5(4) 79-86 (c) The Author(s) 2015 http://herj.lib.unideb.hu Debrecen University Press

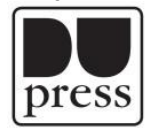

DOI: 10.14413/herj.2015.04.07.

Summary thoughts to the closing research report on the LEARN 'Learning Regions in Hungary: From Theory to Reality' research project, supported by the Hungarian Scientific Research Fund (R-101867) (Principal Investigator: Prof. Dr. Tamás Kozma) Augustus 2015 


\section{The theoretical roots}

From the 1980's onwards, on the basis of a set of inter-directly or indirectly related disciplines, some conceptual elements had been emerged and strengthened which were favorable for the birth of the multiple disciplines common set of "learning regions" concept. Human Resource Management directed attention to empowerment, which is based on trust while is giving room for creativity (Bakacsi, 2004). According to research of the innovation process, the essential element of the innovation process is interactive learning (Lundvall, 1992), which takes place within the framework of evolving interactions between actors. Strengthening the regional dimension indicates the acceptance of the challenge that in order to solve problems and make concepts and plans for the future - beyond the sectoral approach - territorial, regional considerations and interests are needed to take into account and to enforce them (Rechnitzer, 1993). Unique highlight is given to the emergence of direct democracy. In terms of the learning region concept, one of the most important ideological background is the bottom-up theory (Ray, 1999), the bottom-up development. Similarly significant impact on the regional development of thought in reliance on internal resources is the concept of endogenous development. Strengthening of globalization process brought along with the increasing role of local knowledge, especially latent, tacit knowledge which is strongly related to locations. Collective learning is of great importance in shaping of the learning region concept. The relative interpretation of the geographical situation has changed: instead of the importance of closeness to certain centers the access to geographic locations has been the centre of attention. According to Castells in the 'Information Age', instead of 'places in space, the space of places' we are witnessing the processes of 'flows in space, space of flows' (Castells, 2005). Learning activities taking place in terms of learning region in the area of learning space are primarily made up of learnings are displayed in interactions. Learning appears as a key building block in the connection system of those organizations which are capable learning. In the course of evolving cooperation, in network relations learning processes are taken place. The knowledge transfer, knowledge sharing, creation of new knowledge happen along the strands of networks in the non-formal and informal learning processes. Connection points in the networks can be considered as the birth places of the new knowledge (Erdei, G. -Teperics, K. 2014)

The above concepts and correlations provide a theoretical framework for the learning region idea. Among other things, the regional science, innovation theory, management science paved the way to the birth of a new concept, which by adjusting the emphases of new scholarly approaches is leading to the born of a new structure, a new quality using the same building blocks. The appreciation of local knowledge and the role of the local economy, grassroots initiatives, creativity and a broader interpretation of innovation, the importance of implicit knowledge in terms of competitiveness, the role of the partnership in the development of a particular area, were already known before the learning region concept has emerged. By linking these elements and rearranging emphases the emerging learning region concept created a new quality (Benke, 2013: 204). 
Although the new-born concept resulted several debates among the researchers for years (see the summary of Hassink, 2007), up today, all the challenges it has faced, both the regarding theoretical debates and empirical experiences provided us with a very rich source of information and knowledge, which resulted a great support and a solid basis for the development of our country-study.

\section{The Learning Region}

The history of the term 'learning region' goes back to the $70^{\prime}$ and to the 90 's of the last century. The interpretation of the term varies according to the professional background of the authors operating with 'learning region' from different aspects of different sciences. Rooting in various disciplines is leading to the fact that the term covers a variety, a diversity of theoretical concepts of the learning region. The authors of the term are significant researchers and professors of geography, geographic economy and innovation studies. All the different concepts of the learning region theories emphasize the importance of partnership and co-operation between stakeholders in a given region, the key role of universities as innovation partners, the utilization of local knowledge and the support of bottom-up activities, so that the concept of learning region easily became a flagship of the university-based region/city development activities, the lifelong learning movement and offered an appropriate environment for research projects targeting local development with a wide range of regional instruments (Benke, 2014c). Different authors represent certain distinct periods and phases of the history of the learning region, therefore they display various aspects of the topic and draw the reader's attention to different sides and activities related to the rich and rather broad learning region concept.

Referring to some of the most important interpretations, according to Florida (Floria, 1995), learning within and between organizations represents an essential element of the learning region and learning regions are the repositories of knowledge and ideas. The innovation is based on the interaction between economic actors, who are socially and regionally embedded (Morgan, 1997). The learning regions are development coalitions based on regional foundations (Asheim, 1996). The local environment ensures favorable conditions for collaborative learning (Lundvall, 1996). The learning regions are regional innovation strategies (OECD, 2001).

The learning region concept represented a major promise for the development of lifelong learning policy support as it had a strong influence on the development processes. Among others, R3L+ project (Regions and its relationship to Lifelong Learning), TELS (Towards a Learning Society), PENR3L (PASCAL European Network of Lifelong Learning Regions) represents attempts to utilize the message of the learning region concept in the development process of lifelong learning. According to a survey carried out in 2004, there were huge differences in the number of learning regions in Europe. While in Germany the survey reported on 5000 learning regions, in the Netherlands (218) and France (185) a much smaller number of learning regions were registered, according to the survey. Difficulties concerning the application of the learning region concept in the development 
process can be demonstrated by the case of the Learning Regions Network in Germany. Germany has launched appr. 80 projects in the framework of the Learning Regions Network conducted between 2001-2008, and only half of them has become "sustainable". According to experience the objectives and content of the learning region concept did not met always understanding and were not always well-received by the interested decision makers.

\section{The Learning City}

In spite of the fact, that the term 'learning region' was rather flexible since it's first appearance, the failure of some large development project and the changing policy environment could not ensure a supporting environment for learning region pojects any longer and required a new, more easily 'digestible', more concentrated spatial approach for the development works, which led to the emerge of the learning city concepts. A very important policy issue contributed to this shift from the region level to the city level: as the concept of regional equalization has lost its dominance in the regional development policy, large cities with strong university connection - like regional poles -, came into the focus of policy interests as the new targets of regional development, and as an evidence of this process, learning cities came in place of learning regions both in policy and project level.

In 2009, Germany launched the "Learning in Place" program, which indicates the intention of the increased involvement of local stakeholders and local partnerships in the development processes. Indicating the appreciation of the role of 'place', in the level of development policy there was a shift from the elusive, difficult to interpret learning region concept towards a more manageable, easily 'digestible' context area, in which the locality and spatial determinations are especially of great importance.

A number of international development projects have directed on cities (Pallace, TELC, PASCAL Learning City in 2020), which projects are intended - among other things - to develop the "learning performance" of cities, to support the development of lifelong learning by creating multilateral relations between the cities, to develop learning communities and sustainable learning cities, and to support the management of major future challenges of cities (Longworth and Osborne, 2010). Famous samples as learning cities had represented the development projects, like Liverpool, Southampton, Espoo, Gothenburg, Adelaide, Victoria and Beijing. Researchers emphasize that the learning city is not equal to "smart city" nor a "stakeholder society" (Longworth, 2012). Hungarian participation has been displayed in the learning city projects, as Pécs has been involved in the development activity of PASCAL (Németh, 2014). The prominent role of universities in the learning city projects can be considered as one of the most important feature of these projects. 
Projects covering more narrow spatial area than a region, like city-size, city-focused projects, seems to be more appropriate for employing direct policy-led development projects in a network of cities with similar targets and challenges.

\section{The Learning Community}

In recent years, along with the continuation of the discourse on learning regions and learning cities, growing attention is being paid to learning communities, as well. According to the 'classic' vision of the learning community, it implies close co-operation of the local economy, local schools, colleges, universities, professional associations and local government to ensure that the community is a pleasant, livable place for members of the community in all aspects (Longworth, 2012). Faris offers the interpretation of the generic term "learning communities" as a nested concept of social/cultural learning with an expanding scale of learning environments. He identifies the following learning communities: virtual global learning communities, learning communities of place, learning organisations, academic learning communities, communities of practice and learning circles, virtually placed them in a nested 'Russian Egg' (Faris, 2006). Another concept, based on a system approach, starting from the controlled systems is reaching the alive learning systems, deals with the learning communities by considering the principle of sustainable development essential for the future (Clarke, 2009).

It seems, that one of the most recent approaches of the EU tries to grasp and interpret the political messages and mission of the learning region to become more understandable and more 'digestible'. The scientific background of this approach does not refer to regional development nor to regional innovation models. It does not indicate the possible or desirable range of education and training partners. The learning communities are evaluated on the basis of how the members of the communities work together and as they utilize the resources of the communities. Non traditional, new, innovative partnerships have an important role in the formation of learning communities. Regarding this new approach of the EU, all kinds of learning - from the first steps to the highest standard, from the formal to non-formal and informal learning - is viewed as valuable and which enriches the community. Interest and capacity of citizens related to learning considered as the most valuable resources of the learning community (Gejel, 2012).

\section{The Learning Cluster}

Hassink points out that - since there are different clusters in a region - if we are planning to develop a learning region strategy, at first it is necessary to understand those learning processes that take place in the different clusters in the region. In order to avoid the difficulties of learning regions, there was a shift from the concept of the learning regions towards a less normative and more process-oriented concept, the concept of the learning clusters. 
According to this proposal (Hassink: 2007, p. 265), „the learning cluster concept is able to bridge the gap between regional learning - which increasingly crosses the borders of regions and nations due to the globalisation of production networks - and the learning region strategy, which focuses on the regional SMEs active in a variety of different clusters with different characteristics".

It is the advantage of the learning cluster to be less sensitive to the political and administrative boundaries than the learning regions.

\section{Conclusions /messages}

The terms learning region, learning city and learning community often are not clearly separated from each other in the literature. However, there are certain elements, building blocks of the concepts, even citing learning regions (LR), learning cities (LCi), learning communities (LCo) or learning clusters (LCl), which can be considered constant elements and factors. All these concepts emphasize the importance of partnership, cooperation and interaction between stakeholders in a given spatial frame, the key role of universities as innovation partners, the utilization of local knowledge and the support of bottom-up activities in the regional development processes. At the same time, all these spatial units own special characters which make possible to distinguish them from each other.

According to my hypothesis, which is based on research I continued on the learning regions and the learning communities in the project, learning communities may represent the initial point, the "germ" to the formation, to the development of learning regions. Based on the presentation of different approaches to the learning communities, I assume, that the existence of learning communities may form the necessary but not enough condition to the birth of a learning region. I suspect that each learning community types depending on the type - can contribute - in varying degrees - to the formation of learning regions (Benke, 2014a).

The learning region concept has a major positive impact on many scientific areas, including education. It draws attention to the importance of inter- and multi-disciplinary approach in research.

The research on 'Learning Regions in Hungary' raised the possibility that not only the universities can play a key role in eliminating the serious differences in the level of regional development and in supporting the birth of learning regions, but also secondary education, particularly secondary vocational education.

\section{References}

Asheim, B. (1996): Industrial districts as "learning regions": A condition for prosperity? European Planning Studies, 4, 4. p. 379-400.

Bakacsi, Gy. et al (2004): Stratégiai Emberi Erőforrás Menedzsment, Kerszöv, Budapest 
Benke, M. (2013): A tanuló régió - Kihívás és lehetőség. In: ANDL, H. - MOLNÁR-KOVÁCS, Zs. (szerk.): Iskola a társadalmi térben és időben 2011-2012. [II. kötet.] PTE „Oktatás és Társadalom” Neveléstudományi Doktori Iskola, Pécs. p. 200-210.

Benke, M. (2014a): A tanuló régióktól a tanuló közösségekig. In: Dr. Juhász Erika (szerk.): Tanuló közösségek, közösségi tanulás, CHERD, Debrecen. p. 51-70.

Benke, M. (2014b): A tanuló régió - Kihívás és lehetőség. Fejezetek a PhD dolgozathoz. Témavezető: Prof. Dr. Kozma Tamás. (www.academia.edu)

Benke, M. (2014c): The Learning Region - Preface. In: Hungarian Educational Research Journal, 4. 3.

Boekeama, F.-Morgan, K.-Bakkers, S. - Rutten, R. (2000): Knowledge, Innovation and Eceonomic Growth: The Theory and Practice of Leaning Regions. Edward Elgar, Cheltenham.

Castells, M. (1996): The Information Age: Economy, Society and Culture. Volume 1: The Rise of the Network Society. Oxford, Blackwell.

Cities and Regions in the New Learning Economy (2001). Paris: OECD

Clarke, P. (2009): A practical guide to a radical transition: framing the sustainable learning community. Education, Knowledge and Economy, 3. 3. p. 183-197.

Cooke, P. (2008): Regional innovation systems: origin of the species. - International Journal of Technological Learning, Innovation and Development. 3. p. 393-409.

Erdei, G. and Teperics, K. (2014): Adult Learning Activities as the Catalyst for Creating Learning Region. Procedia - Social and Behavioral Sciences, Elsevier, 142. p. 359-366.

Faris, R. and Wheeler, L. (2006): Learning Communities of Place: Situating Learning Towns within a Nested Concept of Social Learning Environments. Australian Learning Communites Conference, Brisbane. http://scholar.google.hu/scholar?q=Wheeler\%2C+L.+and+R.+Faris+\%282006\%29.+Learnng+Com munities+of+Place $\% 3 \mathrm{~A}+$ Situating+Learning+Towns+Within+A+Nested+Conept+of+Social+Learnin g+Environments.+Australian+Learning+Communites\&btnG=\&hl=hu\&as_sdt=0\%2C5 (2015.01.09.).

Florida, R. (1995): Towards the learning region. Futures, 27, 5. p. 527-536.

Gál, Z. (2010): The role of research universities in regional innovation: The case of Southern Transdanubia, Hungary. In: Longworth N, Osborne M (eds.) Perspectives on Learning Cities and Regions: Policy Practice and Participation. Leicester: \&, p. 84-106.

Gejel, J. (2012): Towards Learning Communities. A guide compendium. EU Education and Culture DG, http://www.sosuaarhus-

international.com/dokumenter/Xploit\%20Finals/Xploit\%20Guide\%20-\%20Towards\%20A\%20Le arning\%20Community.pdf. (2015. 01.09.)

Hassink, R. (2007): The learning region: a constructive critique, in: The Learning Region. Foundations, State of the Art, Future. (Ed. Rutten, R. and Boekema, F.) Edward Elgar, p. 263-266.

Kozma, T. (2014) “A tanuló régiótól a tanuló közösségig”. In: Juhász E. (szerk.): Tanuló közösségek, közösségi tanulás: A tanuló régió kutatás új eredményei. CHERD, Debrecen. p. 4-19.

Kozma, T. (2014) : “The Learning Region; A Critical Interpretation.” Hungarian Educational Research Journal, 4. 3.

Kozma, T. (2012):“A művelődési városközpontoktól a tanulórégiókig.” In: PUSZTAI G., FENYŐ I. és ENGLER Á. (szerk.) A tanárok tanárának lenni. Tanulmányok Szabó László Tamás 70. születésnapjára. CHERD, Debrecen. p. 275-298.

Kearns, P., Kearns, D. R. (2010): Some strategies building learning communities and regions. PURE, PASCAL Observatory. $\quad$ http://pure.pascalobservatory.org/pascalnow/pascal-expertise/otherresources/some-strategies-building-learning-communities-and-regions (2015.01.13.)

Longworth, N. (2001): Lifelong Learning and Learning Communities: A Vision for the Future. www.learndev.org/dl/VS3-00h-LL+LC.PDF (2015. 01. 09.)

Longworth, N. (2006): Learning Cities, Learning Regions, Learning Communities. London: Routledge, London. 
Longworth, N. (2012): The Changing Scope of Learning Cities and Regions. http://pie.pascalobservatory.org/sites/default/files/The\%20changing $\% 20 \% 20$ scope $\% 20$ of $\% 20 \mathrm{~L}$ earning\%20Cities\%20and\%20Regions_0.pdf [2015.01.13.]

Lundvall, B-A (ed.) (1992): National Innovation Systems: Towards a Theory of Innovation and Interactive Learning. London: Pinter Publishers

Lundvall, B-A (1996): The Social Dimension of The Learning Economy. DRUID Working Paper No.1. http://www3.druid.dk/wp/19960001.pdf (Utolsó látogatás: 2015.01.08.)

Morgan, K. (1997): The Learning Region: Institutions, Innovation and Regional Renewal. In: Regional Studies, 31, 5. 491-503.

Németh, B. (2006): A tanuló régió szerepe az egész életen át tartó tanulás megvalósításában. Új Pedagógiai Szemle, LVI. 6. p. 72-83.

Németh, B. (2014): The Learning Region Initiative - a Challenging Concept for Higher Education to Promote Regional Development in: Benke, M - Kozma, T. (ed). Hungarian Educational Research Journal 4. 3. Thematic issue on learning regions.

Nyhan, B. (2007): Building learning regions for innovation in Europe: a challenge for education and training. In: Gustavsen, B. - Nyhan, B. - Ennals, R. (eds): Learning together for local innovation: promoting learning regions. Luxembourg: Office for Official Publications of the European Communities (Cedefop Reference series: 68). p. 16-45.

Osborne, M. - Kearns, P.- Yang, J. (2013): Learning inclusive, properous and sustainable urban communties. International Review of Education vol. 58. 4. p.12-36.

Putnam, R. (1993): 'The prosperous community: Social capital and public life'. The American Prospect, 13, Spring, p. 35-42.

Ray, C. (1999): Towards a meta-framework of endogenous development. Sociologia Ruralis 39, 4. p. 521538.

Rechnitzer, J. (1993): Szétszakadás vagy felzárkózás. A térszerkezet alakító innovációk. Győr: MTA Regionális Kutató Központ

Storper, M. (1993): Regional 'worlds' of production. Regional Studies, 27, 433-455.

Wolfe, D. A. (2002): "Social Capital and Cluster Development in Learning Regions." In: Holbrook, J. Adam and Wolfe, David A. (eds): Knowledge, Clusters and Learning Regions. Kingston: School of Policy Studies, Queen's University, 1-36. 